\title{
REPOR TS
}

\author{
Age and Origin of the Perry Formation, Charlotte County, \\ New Brunswick, Canada* \\ WILLIAM H. McILWAINE \\ Ontario Department of Mines, Toronto, Ont.
}

Introduction

The Perry Formation is a sequence of red siltstones, sandstones and conglomerates with interbedded basalt flows and minor tuffs (Table 1). The formation is Upper Devonian in age, based on the evidence of fossil plants (Dawson, 1861, 1862, 1863; Smith and White, 1905). It is exposed in several localities (Figure 1) around the coast of Charlotte County in southwestern New Brunswick, and in eastern Maine where the town of Perry and the type section are located. This study deals only with the outcrops in New Brunswick.

The first studies of the rocks in Canada were carried out by Abraham Gesner (1839). Further studies were made by Bailey (1865), Bailey and Mathew (1870-71), Bailey, Mathew and Ells (1878-79) and latterly by Squires (1927), Alcock (1948, 1959), Alcock and MacKenzie (1960), Alcock and Perry (1960) and Klein (1962). In the United States the first work was carried out by Smith and White (1905) and more recently by Amos (1963) and Rhoades (1963).

\section{Petrological Description}

The following description is based on the exposures of the Perry formation on the St. Andrews Peninsula (Table 1). Most of the exposed section consists of sedimentary strata (conglomerate, sandstone, siltstone) but some basalt ( 4 per cent) and tuff ( 1 per cent) are present.

\section{TABLE I}

PART A:- Generalized Geological Column, Charlotte County, N. B.

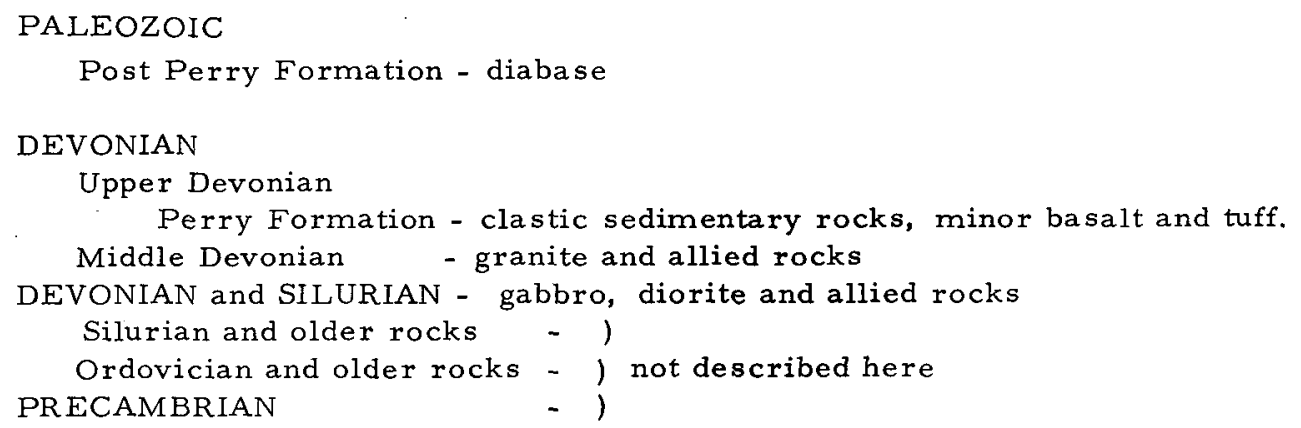

PART B:- Rock types in the Perry Formation in the section measured.

\begin{tabular}{lrc} 
Rock Type & Feet & Percentage \\
\cline { 2 - 3 } Sandstone & 840 & 40 \\
Siltstone & 240 & 11 \\
Conglomerate & 535 & 25 \\
Basalt & 90 & 4 \\
Tuff & 18 & 1 \\
Overburden & 292 & 19 \\
\cline { 2 - 3 }$\quad$ TOTAL & 2115 & 100
\end{tabular}

The basalt is dark greyish-green in land specimen and generally fine-grained, although it is amygdaloidal in part, especially near the top of the flows. The tuff is red and porphyritic,

*Manuscript received September 15, 1967. 


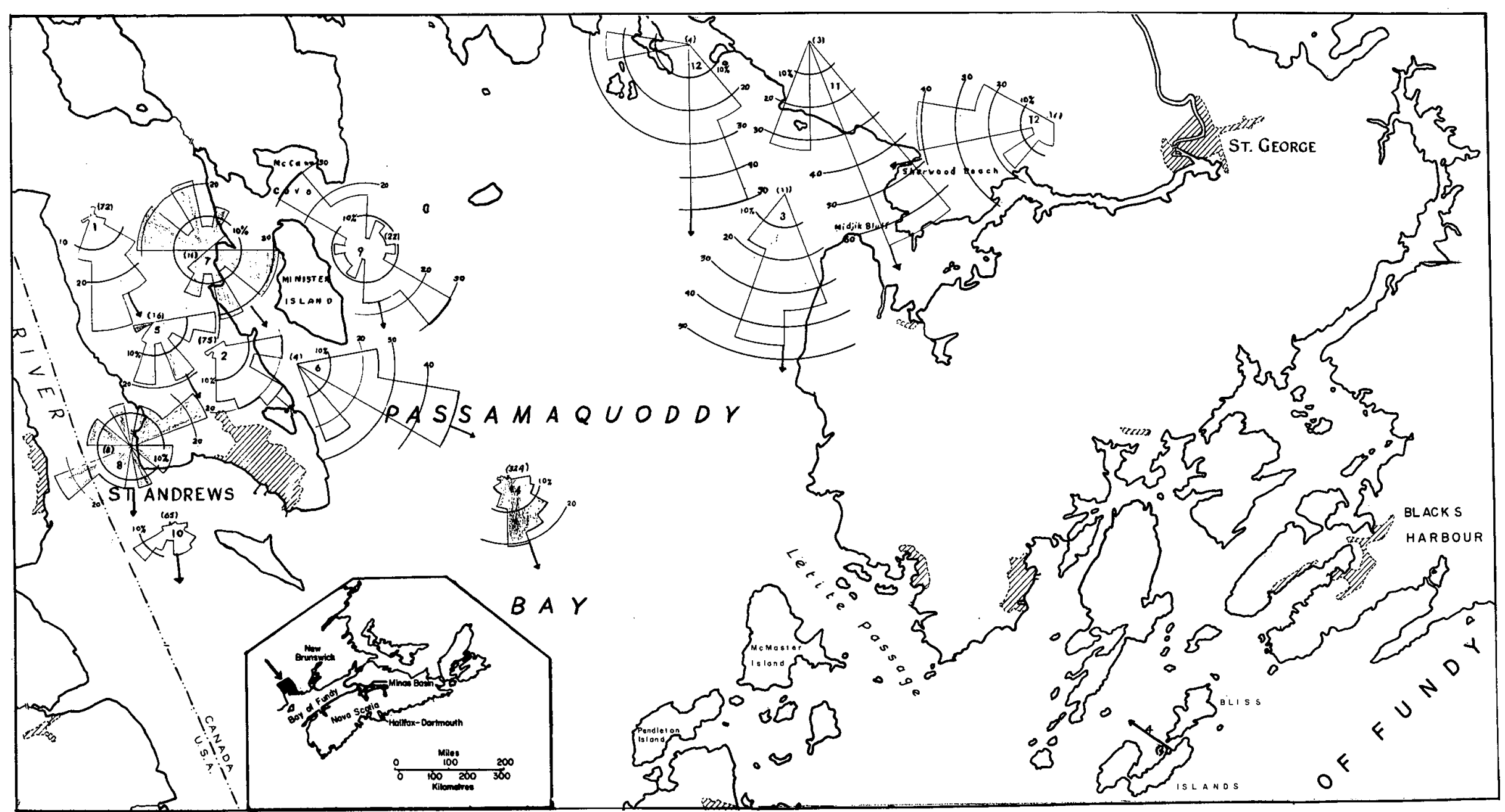

Figure 1. Rose diagrams of paleocurrent distribution in Perry Formation. Key is as follows: (1) (2) (3) (4) are Trough cross-bedding; (5) (6) are channels: (7) (8) are primary current lineation (9) is subsidiary trough structures; (10) (11) (12) (13) are pebble imbrications and (14) is a composite of all paleocurrent vectors. Stations (1) (5) and (7) are located below the basalt and (2) (6) (8) are above. Arrow in the insert sketch points to location of study area. 
containing numerous green rock fragments, up to 4 inches in diameter, and abundant quartz eyes.

Siltstone is widespread and consists mainly of subrounded quartz, with a thin coating of hematite. Feldspar, mica and magnetite are also common, while silica and carbonate are other cementing minerals. The siltstone is red and may be laminated or massive. Reduction spheres are common as well as certain sedimentary structures such as mud cracks, nodular concretions and channel fills.

Sandstone and pebbly sandstone are the most common ( 40 per cent) rock types in the Perry Formation. The pebbly sandstone is distinguished from conglomerate on the basis of pebble density. Where pebbles are less than one inch in diameter and not in contact with other pebbles, the rock is called a pebbly sandstone, and commonly grades into a fine-grained sandstone.

The sandstone varies from pale greyish red. Lenses of greenish grey reduction areas are common throughout, and are generally parallel to the bedding. Trough cross-beds are present and are commoner in the medium-grained units. Quartz is the chief mineral constituent and the grains are sub-angular to subrounded. Feldspar, altered ferro-magnesian minerals and rock fragments are also present. The red coloration is due in part to the oxidation of the iron in the ferro-magnesian minerals and rock fragments to give ferric oxide. It may also occur as a thin coating a round the quartz grains where it serves as a cement. Carbonate, mostly calcite, also acts as a cementing material.

Conglomerates are most common immediately above the basalt flows. The concentration of the pebbles is dense, sorting is generally fair, and the diameter of the pebbles ranges from one quarter-inch to six inches. The matrix consists of a drab grey, medium-grained sand. Calcite is abundant in the conglomerate near the base of the formation.

A brief statistical study of the pebble composition of the conglomerate was made in the following manner. An area 15-inches square was marked off on the outcrop face, and the pebbles in that square were counted according to the rock type. At least 100 pebbles in each square were so classified and divided into the following groups: (1) purplish-brown rhyolite porphyry (similar to the volcanic rocks of the Mascarene Group), (2) vein quartz, (3) green metasedimentary rock (similar to the Charlotte Group), (4) brown sandstone (re-worked Perry Formation), (5) granitic rocks, and (6) miscellaneous (including light-coloured rhyolite, brown sandstone where minor, and granitic rock where minor).

Structural Geology

The consistent gentle dips throughout, except in the Blacks' Harbour region, show that the Perry Formation was gently folded with much of the rock at or near the original dip. Minor faulting took place in the Perry Formation with displacements of three to four feet. On Pendleton and McMaster Islands the base of the Perry is in fault contact with the basement rock.

Sedimentary Structures, Paleocurrents and Paleogeography

Several types of structures and fabrics were studied in order to determine the environment of deposition, the routes of sedimentary transport and the location of the source area. These features include pebble imbrication, primary current lineation, trough cross-bedding, and channels. The vector azimuthal mean of the paleocurrent direction determined from some of these structures is given in Table II.

Numerous intermontane troughs or cuvettes were one of the results of the Acadian Orogeny, and the Perry Formation was deposited in one of these cuvettes. The main source of sediments lay to the northwest. Flow conditions in both the upper and lower flow regimes are indicated mainly by primary current lineation (Allen, 1964), and the upper part of the lower flow regime is indicated by trough cross-bedding (Harms and Fahnestock, 1965). The greater abundance of trough cross-bedding indicates most of the deposition took place in the lower flow regime. Probably fairly consistent streams flowed rapidly out of the surrounding highlands. At the base of the highland the stream velocities were reduced, causing alluvial fans to be deposited and spread over the valley floor. Periodic rain storms of high intensity added greater volumes of water to the drainage system, which resulted in a higher flow regime in the depositional area. Sheet-flooding would also be common at this time. Near the southern end of the St. Andrews 
peninsula the rocks are generally fine-grained, and braided channels were probably abundant as suggested by the presence of more erratic trend indicators.

TABLE II - Statistical results of paleocurrent studies

\begin{tabular}{|c|c|c|c|c|}
\hline Structure & Location & $\begin{array}{l}\begin{array}{l}\text { Number } \\
\text { of } \\
\text { Readings }\end{array} \\
\end{array}$ & $\begin{array}{l}\text { Vector } \\
\text { Azimuthal } \\
\text { Mean } \\
\end{array}$ & $\begin{array}{l}\text { Standard } \\
\text { Deviation } \\
\end{array}$ \\
\hline Troughs & St. Andrews (B) & 72 & 154 & 35 \\
\hline 11 &.$" \quad(A)$ & 75 & 130 & 33 \\
\hline$" 1$ & Sherwood Beach & 11 & 180 & 3 \\
\hline " & Bliss Island & 3 & 305 & 7 \\
\hline Channels. & St. Andrews (B) & 16 & 150 & 42 \\
\hline$"$ & $" 1$ (A) & 4 & 110 & 18 \\
\hline Current Lineation & (B) & 14 & 140 & 39 \\
\hline$" 11$ & (A) & 8 & 175 & 51 \\
\hline Subsidiary Troughs & (A) & 32 & 165 & 50 \\
\hline Imbrication & 11 & 65 & 175 & 50 \\
\hline$" 1$ & S. of Oven Head & 3 & 160 & 12 \\
\hline$" 1$ & Sherwood Beach & 17 & 255 & 31 \\
\hline$\cdot "$ & Ovenhead & $\frac{4}{324}$ & $\frac{165}{160}$ (aver & $\frac{54}{50 \text { Tave }}$ \\
\hline
\end{tabular}

(A) - above basalt, (B) - below basalt.

Continental instability is indicated by the presence of volcanic rocks. Following the outpouring of the basalt, especially in the St. Andrews area, great volumes of detritus were transported into the basin, thus resulting in the deposition of the conglomerates. The extrusion of the basalts also changed the direction of the paleocurrents for a period of time. In conclusion it appears that the paleocurrents flowed from the northwest to the southeast in the western part of the cuvette, with limited data indicating northwesterly flowing paleocurrents in the southeastern part.

\section{$\underline{\text { References cited }}$}

ALCOCK, F. J. , 1948, Campobello, New Brunswick. Geological Survey of Canada Map 964A, 1 inch to 1 mile.

, 1959, Geology of Musquash area, New Brunswick. Geological Survey of Canada Map 1084A, 1 inch to 1 mile.

, and MacKenzie, G.S., 1960, Geology of St. Stephen, New Brunswick. Geological Survey of Canada Map 1096A, 1 inch to 1 mile.

, and Perry, S. C., 1960, Geology St. George, New Brunswick. Geological Survey of Canada Map 1094A, 1 inch to 1 mile.

ALLEN, J.R. L. 1964, Primary Current Lineation in the Lower Old Red Sandstone (Devonian), Anglo Welsh Basin. Sedimentology Vol. 3, p. 89-108.

AMOS, D.H., 1963, Petrology and Age of Plutonic Rocks, Extreme Southeastern Maine, Bull. Geol. Soc. America, Vol. 74, p. 169-194.

BAILEY, L. W. , 1865, Observations on the Geology of Southwestern New Brunswick. Printed by order of the House of Assembly, Fredericton, N. B.

, and Mathew, G. F., 1870-71, Preliminary Report on the Geology of Southern New Brunswick. Geological Survey of Canada Summary Report, p. 13-239. 
BAILEY, L. W. and ELLS, R. W. , 1878-79, Report on the Geology of Southern New Brunswick. Geological Survey of Canada Summary Report, p. 1D-26D.

DAWSON, J. W., 1861, On the Pre-Carboniferous Flora of-New Brunswick, Maine, and Eastern Canada. The Cdn. Naturalist and Geologist, Vol. 6, p. 161-180. 1862, On the Flora of the Devonian Period in North-Eastern America. Quarterly Jour. Geol. Soc. London, Vol. 18, p. 296-330. 1863, Further Observations on the Devonian Plants of Maine, Gaspé and New York. Quarterly Jour. Geol. Soc. London, Vol. 19, p. 458-469.

GESNER, 4., 1839, Report on the Geological Survey of the Province, by Abraham Gesner; New Brunswick Legislative Assembly.

HARMS, J. C. and FAHNESTOCK, R. K., 1965, Stratification and Bed Forms and Flow Phenomena (with an Example from The Rio Grande) Soc. Econ. Palaeontologists and Mineralogists Special Paper No. 12, p. 84-110.

KLEIN G. de V., 1962, Triassic Sedimentation, Maritime Provinces, Canada. Bull. Geol. Soc. America Vol. 73, p. 1127-1146.

RHOADES, D. A., 1963, The Geology of the Perry Formation. M. Sc. Thesis, U. of Maine.

SMITH, G. O, and WHITE, D., 1905, Geology of the Perry Basin. U. S. Geol. Survey Professional Paper 35, 102 p.

SQUIRES, H. D., 1927, Geology of St. George Map Area. Manuscript in Library of Geological Survey of Canada. 